\title{
Commercial law reform in the Russian Federation
}

\author{
by K V S K Nathan
}

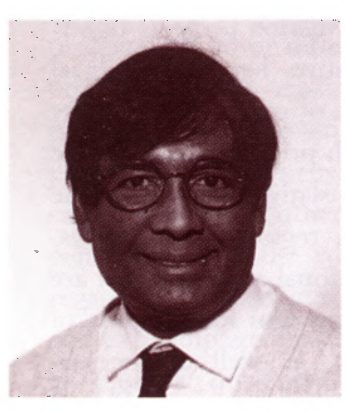

KVS K Nathan

The privatisation of state-owned undertakings engaged in economic and commercial activities has become the staple of economic policies of developing countries and even many developed countries. In the Russian Federation, the enormity of the process is only now beginning to be understood fully. This article discusses the interventions by the World Bank and the European Commission to introduce a new legal order in the country to protect private property and economic rights and complete the transformation from a socialist to a market economy.

$\mathrm{T}$ the struggle for economic reform in Russia is handicapped by an unwieldy legal system that has not been successful in providing a predictable legal and regulatory framework within which investments and market activities can take place. There is little assurance that everybody will obey the law and that contracts and other transactions lawfully entered into will be respected. There is also insufficient assurance that those who cause damage and injury to others by not doing so can be compelled by the courts system to compensate them. The judiciary has not adjusted fully to the new legal and economic order and has not been effective in disciplining the political and bureaucratic establishment and curbing misconduct in the market by privileged entrepreneurs. Legal education is yet to be overhauled and the legal profession has failed to seize the opportunities to make its mark on the historic changes in the country. The mistrust of the general business community in the entire system has not abated and segments of the public are even nostalgic for the past.

\section{HIGHER PRIORITY}

law reform for the legitimisation of the new economic order, the adoption of civil procedural rules to improve speed and efficiency in court proceedings and the reception of evidence under rules consistent with basic standards of fairness and justice must have a much higher priority in the scheme of things.

The law during the socialist era did not recognise individual civil and human rights as the Western democracies understand them and disallowed private ownership of land and private commercial contractual rights, but at least the law was predictable and applied and enforced quite effectively by a quasijudicial system that acted in accordance with the rules of law, procedure and evidence prevailing at that time. In fact, the Arbitrazh Courts were required by the Soviet Government to apply the law rather than economic policy considerations in the resolution of disputes between state enterprises. Arbitrazh Courts are commercial courts and include appellate divisions of first and second instances. The Soviet administration conducted its bureaucratic functions according to the law and the people were constrained to follow the law voluntarily or involuntarily even though the law was bad law by Western standards of fairness and justice and the legislative and law enforcement measures were not democratic.

The turmoil in the legal system and the judiciary was actually brought about by government policy to press ahead with radical economic reform with support and advice from the World Bank, the European Bank for Reconstruction and Development and bilateral aid agencies such as USAID. These institutions applied significant pressure to accelerate the transformation of the economy through their loans and credits. Unfortunately, the legislative activity needed to validate the new economic order could not keep pace with the demands of these institutions. As a result, the economic reforms and sector programmes were pushed through in many instances in violation of the prevailing legal order.

Thus a culture has grown up among those engaged in entrepreneurial activities and, indeed, those in government entrusted with the task of divesting the state's enormous portfolio of valuable assets, of freely ignoring the law for the sake of implementing policy. The courts were helpless because vestiges of the old law remained, even though a new Constitution came into force into force in December 1993 and nullified those parts of the old law and government actions not in compliance with the provisions of the Constitution; however, it also opened up gaps in the legal framework. Much of the damage done in economic terms is irreparable. It is in this context that the performance of the legal system and the judiciary should be measured and steps taken on a countrywide scale to introduce law and judicial reform in the country. 


\section{LAW REFORM}

In other words, law reform for the legitimisation of the new economic order, the adoption of civil procedural rules to improve speed and efficiency in court proceedings and the reception of evidence under rules consistent with basic standards of fairness and justice must have a much higher priority in the scheme of things. The Constitution by itself is unworkable. The law should provide for:

(1) the transfer of state ownership of natural and other key economic resources to private ownership under conditions beneficial to growth in the overall economy;

(2) the definition and protection of private rights of ownership and disposition of property and enforcement of contractual obligations;

(3) the establishment of a competitive market in goods and services;

(4) due process in the courts and tribunals as we know it in the advanced democratic societies; and

(5) judicial review of actions taken by the executive and bureaucrats affecting the rights of the citizen.

It is apparent that the improvement of the implementation of law and procedure, the training of judges and lawyers and the education of both the business community and the general public to trust the legal and court systems to maintain law and order in the market have to be carried out in a legal and economic environment that is in a state of flux. This is a delicate exercise and therefore the government focus on the massive training efforts which are under way with the aid of foreign governments, the World Bank and the European Union should be directed at understanding and establishing the basic legal norms and principles of a private market economy and motivating the judiciary to break free from political and bureaucratic interventions.

The judges should be encouraged to adopt an activist role, corresponding to the traditions of common law judges, and through their judgments to lay down rules of conduct in the market, consistent with those basic norms and principles, until the legislative bodies intervene with appropriate legislation. The law-making power of the judges may be crucial at this point in time in the history of Russia.

\section{INTERVENTION BY THE WORLD BANK AND EUROPEAN COMMISSION}

The importance of the Law Reform Project launched by the World Bank in 1996 and the establishment of the Committee for legislative priorities in the economic sphere and the Academy of Justice in 1998 cannot be emphasised enough, although these steps have come many years too late. The implementation of the project is about mid-stream, but information on the actual progress with the World Bank project and its effectiveness so far is not available to the public. Progress reports made by Bank staff, including lawyers, are customarily for internal review only. The European Commission is now pitching in with its own project and this article is a commentary on the scope of work in the terms of reference proposed for that project. Proposals from consultants were invited recently by the government to carry out the European Commission funded project on a competitive basis and the appointment of the successful consultants is expected shortly. Work will commence soon thereafter.

\section{ROLE OF JUDGES}

The judges should be encouraged to adopt an activist role, corresponding to the traditions of common law judges, and through their judgments to lay down rules of conduct in the market, consistent with those basic norms and principles, until the legislative bodies intervene with appropriate legislation. The law-making power of the judges may be crucial at this point in time in the history of Russia.

The World Bank and European Commission projects rightly emphasize the resolution of administrative, legal and judicial problems associated with the enactment of primary, secondary and subsidiary legislation in Russia. Both projects will examine the problems of co-ordination of the legislative processes at the federal, state (i.e. republics, territories, regions, major cities, autonomous region and autonomous national areas - which are equal subjects of the Russian Federation) and lower levels of government and public administration, as well as the coordination of legislative activity among the various federal agencies.

The division of legislative powers between the federal and state governments is set out in the Russian Constitution, which expressly provides for the limits of the jurisdiction of the federal government and the joint jurisdiction of the federal and state governments. In addition, four treaties have been concluded between federal agencies and subjects of the Federation, delimiting their respective jurisdictions and powers. The residual power of legislation rests exclusively with the states but the Constitution is very clear that federal law overrides state law. Timing will obviously be an issue where the joint jurisdiction of the federal and state governments is exercised.

Timing may not be a critical factor generally, however, because in the event that state law is in conflict with federal law at any point in time, it will be the duty of the judge to resolve the conflict one way or another following the rules of interpretation laid down by the Constitution or other instrument and the general law. It may be unrealistic to hope that popularly elected members of legislative bodies drawn from different parties at the federal and state levels can be induced to commit themselves to a timely passage of legislation. In practice, it will be difficult to co-ordinate the passing of state legislation with the federal authority. It will be impractical to tie the legislatures to a timetable for passing of specific legislation or for consultations and approval.

Nonetheless, attempts should be made to examine the process involved in the exercise of joint jurisdiction by the federal and state governments and introduce some structural arrangements for consultations between federal and state legislators to enable the passage of legislation by the respective bodies in a coordinated manner. In the meantime, however, priority should be given to the training of judges in the proper interpretation of statutes generally and the resolution of conflicts between federal, state and other laws and regulations. The fact that economic life goes on while law reform issues are being studied and new legislation is being planned means that the government, with the 
assistance of its foreign advisers and consultants, has to perform its tasks of implementation of the law, legal training and education within a legal framework that is deficient in many respects and within an imperfect court environment and legal profession.

\section{CO-ORDINATION BETWEEN THE WORLD BANK AND EUROPEAN COMMISSION}

It has to be noted that the scope of the work under the World Bank project is substantially the same as under the European Commission project in regard to some of the areas of concern, namely legal drafting, dissemination of legal information and judicial reform - except that the World Bank project will be dealing with matters primarily at the federal level. Although both projects will cover different areas of the Russian Federation, in order to obtain maximum practical benefits from the two projects the government should make efforts to adopt an overall program which provides for the respective projects to supplement each other and for the later project to establish continuity with the work done under the earlier project in regard to the specific reforms, training and education proposed and to be implemented. It would be seriously counterproductive to embark on entirely new methodology to execute the European Commission project and to introduce reforms and policy signals that conflict with the earlier World Bank project.

The immediate objective of the government should be to ensure that the reforms to be implemented under the two projects in the selected parts of the Federation should themselves not result in conflict and disunity and that the reforms instituted in the pilot areas can be replicated across the country. The overall objective should be the development of a trusted uniform body of jurisprudence and justice throughout the country.

The task of the government will be difficult without the cooperation of the foreign agencies that are assisting the government. Unfortunately, there is little evidence of meaningful collaboration between the World Bank and the European Commission and it is the observation of the present writer that the delivery of technical assistance per se and not the achievement of credible results has become the driving force behind the two bodies. Both the World Bank and European Commission projects will be concerned essentially with studying the overall processes involved in the drafting of laws, decrees, resolutions and regulations and inter-agency co-ordination and implementing their findings in the context of assisting in the drafting and passing of specific legislation to continue the transition to a market economy.

The obvious areas of legal regulation to be addressed by the government should include legislative measures to guarantee a competitive market in goods and services with easy entry and exit provisions and laws against abuse of a dominant position, laws to protect intellectual property rights and safety and health regulations and provisions for judicial review of actions by bureaucrats. Without risking duplication of work under the World Bank project, the scope of work under the European Commission project should be enlarged to identify gaps and impediments in the existing legal framework and assist the federal, state or other authority to introduce the necessary legislation as a matter of urgency. Surprisingly, both projects ignore the backbone of a free market economy, namely a competitive law framework and an authority to enforce the provisions of the law prohibiting any practice that impedes or distorts competition.

\section{THE EUROPEAN COMMISSION PROJECT}

The European Commission divides its project into three components. Briefly, they are:

- improved implementation of the law in the regions;

- improved application and enforcement of the law by the Arbitrazh Courts;

- improved access to the legal system.

The first component's stated objective is to improve implementation of the law in the area of economic activities in four selected regions. The expression 'implementation of the law' in contrast to the expression 'application and enforcement of the law' in the second component of the project is confusing and may be the result of poor translation of the original terms of reference, which are in French. The European Commission addresses in the first component not only the problem of coordination of the legislative processes and legal draftsmanship and law making but also the problem of compliance with the law by politicians, administrators and business community. By the expression 'application and enforcement of the law' the European Commission evidently addresses the problems linked to the proper adjudication of matters brought before the Arbitrazh Courts.

\section{BENEFITS CAN EVAPORATE}

The benefits of merely conducting studies and implementing classroom-type training programmes on an ad hoc basis can evaporate very quickly once the technical assistance consultants leave the country.

The proper selection of the four pilot regions to improve implementation of the law would be the key to the success of the project. The regions should invariably have a legal system which is implementable, meaning that:

(1) some law reform has already taken place;

(2) the vestiges of the law of the socialist era is of no consequence; and

(3) the gaps in the legal framework are not substantial.

On the other hand, the selection should also include two poorlyperforming regions in order that the special problems facing these regions can be assessed and resolved, thereby averting a continuation of the deterioration of the business climate in those regions.

In the first project component, the technical assistance consultants will form two working groups to study specific areas of legal regulation. The studies to be undertaken by the working groups should be directed at:

(1) examining the legislative processes of the federal government, federal agencies and state governments;

(2) inventorying existing legislation covering economic and commercial activities at the federal and state levels; 
(3) uncovering discrepancies and conflicts and ascertaining the nature of the co-ordination problems; and

(4) identifying gaps in legislation relating to economic and business activities.

It is hoped that the consultants will be provided with Russian counterparts to collaborate with the consultants in this exercise and learn the methodology followed in the conduct of the studies.

The objectives of these studies are to develop training materials and course contents to:

(1) educate legislators, administrators and the business community in the economic and financial benefits of compliance with the law;

(2) elaborate legislative processes with a view to ensuring that legislative activity at all levels of government are compatible and free of conflicts and inconsistencies; and

(3) prepare draft legislation in specific areas of concern.

With regard to the training in legal draftsmanship, there should be a practical element in the accomplishment of the first component of the project, besides conducting studies, seminars, training courses and workshops, in that the two working groups to be formed in each selected region should be required to assist the region in the drafting of specific legislation to deal with problems in the market (such as excessive pricing and monopolies) and to agree with the regional governments on a framework for the orderly and timely passage of bills through the legislative machinery. The benefits of merely conducting studies and implementing classroom, type training programmes on an ad hoc basis can evaporate very quickly once the technical assistance consultants leave the country.

\section{UNIFORMITY NEEDED}

The immediate objective of the government should be to ensure that the reforms to be implemented under the two projects in the selected parts of the Federation should themselves not result in conflict and disunity and that the reforms instituted in the pilot areas can be replicated across the country. The overall objective should be the development of a trusted uniform body of jurisprudence and justice throughout the country.

The improvement of application and enforcement of the law under the second component will also be undertaken in the same four regions selected for attention under the first component. The work of the consultants will consist essentially of conducting educational courses, seminars and workshops for the training of judges in the Arbitrazh Courts. The target groups to be addressed in the second project component should be widened to include administrators in quasi-judicial posts, arbitrators and law teachers responsible for vocational training in law schools. Part of the culture inherited from the old Soviet system is the submission of the judiciary to senior party officials. The education of representatives of the various political parties on the role of the judges in a society subject to the rule of law and the importance of respecting all decisions of a court of law should be included in the implementation of the second project component. This project component will also set up an on-line capability to aid research of legal sources and access to legal information. The training program will include a course of training of instructors to continue the training of the judiciary after the departure of the consultants, who will leave behind complete sets of training materials and equipment.

Unfortunately, the terms of reference for the most part do not go beyond the implementation of classroom-type training programmes. Therefore, in order to structure a practical element into the second project component, the technical assistance experts should be permitted by the courts to observe proceedings in a real setting and discuss ex post their findings with the judges involved. The experts will limit their advice to procedural and evidential matters and not on findings of fact or law, although it is admitted that in some instances the advice might conceivably affect the outcome of the case or other matter before the court (in which case it may be necessary first to see if this would be illegal as tantamount to influencing the work of appointed judges). The experts should be accompanied by law students and sit in all the courts of the four regions.

With regard to the third project component, emphasis should be placed on the establishment of the legal advice bureaux or 'legal clinics'. These clinics should be established in sufficient numbers to cover each selected region and will not only give advice on specific matters to those sceking legal assistance but also be a general information centre for any one who wishes to be educated in regard to law and justice in the particular region. The legal clinics should preferably work out of law schools and include law students, who will gain experience on a practical level by proffering legal advice to real clients and practising lawyers who want to participate. The clinics should travel around the region holding clinics in each jurisdiction.

\section{CONCLUSION}

The massive classroom-style formal training programmes envisaged in the project alarm the present writer, whose experience with World Bank projects is that the results are nearly always disappointing. There are usually very difficult logistic problems. Many consultants do not possess the flexibility to cope with unexpected local problems and simply mark time when the resources promised by the government do not materialise. Besides, the government has to provide adequate incentives and make time available for the right candidates to participate in the training programmes. Government inputs are also never on time and funding to continue the training programmes is not guaranteed. Training all but ceases when the loan funds run out and foreign technical assistance personnel depart. Therefore, in order to establish a routine in-house training capability in the country, all training courses, seminars, workshops and the like under the project should be delivered through law schools, academies and training institutions in the respective regions where they are conducted, and a promise shoul be extracted from the government that it will fund a continuation of the training programmes after the departure of the technical assistance consultants.

It is not uncommon too for development institutions such as the World Bank to overestimate the need for training in the developing countries, and Russia is much unlike any other developing country. The old Russia was a super power, which meant that it had a formidable intellectual, organisational and 
management capability to hold a vast country of many nations together and to develop the technology that put it ahead in space and military strength. Much of judicial independence is affected by the political culture, the politicians themselves and the bureaucrats, rather than any inherent lack of intellectual capacity on the part of lawyers and judges to understand and put into practice Western democratic concepts.

The World Bank and the European Commission may have to look at educating the politicians and bureaucrats by means other than formal training programmes (for example, by requiring investors from their own member countries to encourage the government to establish a secure legal order by refusing to bend the rules and yield to improper transactions, and by diplomatic means). In the present writer's opinion, the judges by and large are aware of their role and have the intellectual capacity to adjust quickly to the new conditions in Russia - provided the politicians and bureaucrats allow them that freedom.
Dr K V S K Nathan

Barrister/Arbitrator, Italy

\section{Submission of articles}

Readers of Amicus Curiae are welcome to submit contributions (not exceeding 3000 words) for publication. Information, including author style notes, is available on the Internet at:

http://ials.sas.ac.uk/amicus.htm

Please contact Julian Harris for further information at:

Institute of Advanced Legal Studies

17 Russell Square, London, WC1B 5DR

E-mail:julian.harris@sas.ac.uk

\section{Eastern European Newsletter}

The Eastern European Newsletter focuses on the tax regimes affecting commercial transactions in the developing markets of Central and Eastern Europe and the legal environment for Western investors, their advisers and business partners.

\section{Your subscription includes}

- Newsletter - Eastern European Newsletter issued monthly

- Index - Monthly cumulative index supplement

- Binder - To hold the newsletters and index supplement

\section{Key benefits}

- Up-to-date - a monthly selection of articles on various business-related topics keeps subscribers up to date with the legislative changes in a number of Central and Eastern European states.
- Authoritative - written by experts from law, accounting and consultancy firms operating in Central and Eastern Europe, you can rely on the material to be accurate and authoritative.

- Accessible - the newsletter format is ideal for coverage of the ever-changing systems in these developing economies.

- User-friendly - the cumulative annual index and frequent cross-referencing allow easy access to current and past issues.

Countries covered includes: Albania $\bullet$ Baltic States • Bulgaria • CIS • Croatia • Czech Republic • Hungary • Poland • Romania • Russian Federation • Slovakia • Slovenia • Ukraine

\section{CCH@NEW LAW}

